\title{
Molecular characterization of Leptospira sp. strains isolated from human subjects in São Paulo, Brazil using a polymerase chain reaction-based assay: a public health tool
}

\author{
Eliete C Romero/ ${ }^{+}$, Paulo H Yasuda*
}

\author{
Laboratório de Leptospirose, Divisão de Biologia Médica, Instituto Adolfo Lutz, Av. Dr. Arnaldo 355, $9^{\circ}$ andar, \\ 01246-902 São Paulo, SP, Brasil *Universidade de Santo Amaro, Santo Amaro, SP, Brasil
}

\begin{abstract}
A polymerase chain reaction (PCR)-based assay which amplifies repetitive DNA elements present within bacterial genomes was used to characterize and differentiate Leptospira sp. Thirty-five strains from a reference culture collection and 18 clinical isolates which had been previously analyzed by cross agglutinin absorption test (CAAT) were evaluated by this technique. PCR results from analysis of the reference culture collection showed no bands corresponding to serogroups Australis, Autumnalis, Bataviae, Celledoni, Cynopteri, Djasiman, Panama, Pomona, Pyrogenes, and Tarassovi. However, the PCR method was able to clearly discriminate the serogroups Andamana, Ballum, Canicola, Grippotyphosa, Hebdomadis, Icterohaemorrhagiae, Javanica, Sejroe, Semaranga, and Shermani. Clinical isolates previously characterized by CAAT as serovar Copenhageni, serovar Castellonis, and as serovar Canicola were in agreement with PCR results. The clinical isolate previously characterized as serovar Pomona was not differentiated by PCR. Forty additional clinical isolates from patients with leptospirosis obtained in São Paulo, Brazil were also evaluated by this PCR method. Thirty-nine of these were determined to belong to serogroup Icterohaemorrhagiae (97.5\%) and one to serogroup Sejroe (2.5\%). These results demonstrate that the PCR method described in this study has utility for rapid typing of Leptospira sp. at the serogroup level and can be used in epidemiological survey.
\end{abstract}

Key words: leptospirosis - molecular characterization - polymerase chain reaction - Leptospira interrogans

Leptospirosis, caused by pathogenic members of the genus Leptospira, is one of the most widespread zoonotic diseases in the world (Faine et al. 1999, Levett 2001, Bharti et al. 2003). Potential sources of infection can be identified most easily by determining the serovar associated with an outbreak of the disease. Certain serovars are often associated with specific mammalian hosts and with the symptoms and severity of the disease.

The genus Leptospira consists of a diverse group of pathogenic and saprophytic spirochetes, currently classified into 17 genomospecies based on DNA-DNA hybridization studies (Faine et al. 1999, Levett 2001).

Efforts have been devoted to the identification of new leptospire isolates. However, our understanding of the circulating serovars is still deficient. For public health purposes in Brazil, identification of at least the most important and most common pathogenic strains is very useful.

Currently, there are various antigenic and genetic methods for the characterization and identification of leptospires (Dikken \& Kmety 1978, Korver et al. 1988, Hermann et al. 1991, Perolat at al. 1994, Faine et al. 1999, Barochii et al. 2001). At the serogroup level, microscopic agglutination tests with group-specific rabbit antisera can be used. To determine the serovar, cross-agglutinin absorption test

${ }^{+}$Corresponding author: eliete_romero@yahoo.com.br Received 25 November 2005

Accepted 5 May 2006
(CAAT) with rabbit antisera is the standard method (Dikken \& Kmety 1978). The last one is tedious and timeconsuming, requiring the maintenance of a comprehensive collection of serovar reference strains and the preparation of the corresponding rabbit antisera. The few strains that have previously been isolated in São Paulo, Brazil were originally classified on the basis of their antigenic traits following the conventional serotyping methods, i.e. CAAT with rabbit antisera (Sakata et al. 1992).

Serovar characterization and identification based on CAAT results are not fully satisfactory as these results do not always concur with the genetic classification originally proposed on the basis of DNA-DNA hybridization studies (Yasuda et al. 1987, Ramadass et al. 1992). CAAT is used mainly in cases of new strains representing new serovars or in cases of problematic isolates. However, this method cannot be used for routine identification.

Although considerable difficulties are encountered in the classification of leptospires at serovar level, this classification system remains as a standard to intra-species differentiation. Serovar identification has become faster with the introduction of genetic typing methods that can serve as supplementary or alternative typing systems to identify a set of serovars causing human and animal disease. These genetic typing methods can identify strain differences at the serovar or serogroup level.

The present study was undertaken with the specific objective of examining clinical isolates by using a polymerase chain reaction (PCR) assay, using a primer from repetitive DNA elements present within bacterial genomes. Also, the PCR method was applied to analysis of strains isolated in São Paulo, Brazil. 


\section{MATERIALS AND METHODS}

Leptospira reference strains - Table shows the serovars selected from the reference culture collection for evaluation by the PCR assay. The choice of the serovars was based on the serogroups known to be prevalent in São Paulo, Brazil by serology and isolation methods (Correa et al. 1971, Sakata et al. 1992, Romero et al. 2003). As the majority of Brazilian isolates belong to serogroup Icterohaemorrhagiae (Sakata et al. 1992, Romero et al. 2003), seven serovars from this serogroup were evaluated. Also, a saprophytic strain serovar Patoc was included in this study.

Clinical isolate strains - Forty strains were isolated from patients with leptospirosis obtained between 1995 and 1999, in the city of São Paulo, Brazil. All strains were isolated from blood except one which was isolated from urine. Eighteen strains isolated from patients and characterized by CAAT by Sakata et al. (1992) were included to make fingerprint comparisons.

All strains were stored in Ellinghausen-McCulloughJohnson-Harris (EMJH) medium (Difco) containing 0.2\% $\operatorname{agar}(\mathrm{w} / \mathrm{v})$ at room temperature and transferred into fresh media every three months.

Culture conditions and preparation of DNA - Strains were grown in $5 \mathrm{ml}$ of EMJH liquid medium at $30^{\circ} \mathrm{C}$. DNA of the bacterial strains was extracted following the method described by Barochii at al. (2001) with some modifications. Exponentially growing leptospiral cultures were centrifuged at $12,000 \times \mathrm{g}$ for $60 \mathrm{~min}$ at $4^{\circ} \mathrm{C}$. The resulting pellets were washed twice with distilled water, resuspended in distilled water to approximately $10^{7}-10^{9}$ cells $/ \mathrm{ml}$ and boiled for $15 \mathrm{~min}$ to release the DNA.

TABLE

List of Leptospira reference strains analyzed by polymerase chain reaction based on the serogroups known to be prevalent by serology and isolation methods in São Paulo, Brazil and the saprophytic serogroup Semaranga

\begin{tabular}{|c|c|c|c|}
\hline Serogroup & Serovar & Strain & Genomospecies \\
\hline Andamana & Andaman & CH11 & L. biflexa \\
\hline Australis & Australis & Ballico & L. interrogans \\
\hline Australis & Bangkok & Bangkok D 92 & L. interrogans \\
\hline Autumnalis & Autumnalis & Akiyami A & L. interrogans \\
\hline Autumnalis & Butembo & Butembo & L. kirschneri \\
\hline Ballum & Castellonis & Castellon 3 & L. borgpetersenii \\
\hline Ballum & Ballum & Mus 127 & L. borgpetersenii \\
\hline Bataviae & Bataviae & Van tienen & L. interrogans \\
\hline Bataviae & Brasiliensis & An 776 & L. santarosai \\
\hline Canicola & Canicola & Hond Utrecht IV & L. interrogans \\
\hline Canicola & Bafani & Bafani & L. kirschneri \\
\hline Celledoni & Celledoni & Celledoni & L. weilii \\
\hline Celledoni & Anhoa & LT 90-68 & L. borgpetersenii \\
\hline Cynopteri & Cynopteri & $3522 \mathrm{C}$ & L. kirschneri \\
\hline Cynopteri & Tingomaria & M 13 & L. santarosai \\
\hline Djasiman & Djasiman & Djasiman & L. interrogans \\
\hline Djasiman & Sentot & Sentot & L. interrogans \\
\hline Grippotyphosa & Grippotyphosa & Moska V & L. kirschneri \\
\hline Grippotyphosa & Valbuzzi & Valbuzzi & L interrogans \\
\hline Hebdomadis & Hebdomadis & Hebdomadis & L. interrogans \\
\hline Hebdomadis & Kremastos & Kremastos & L. interrogans \\
\hline Icterohaemorrhagiae & Icterohaemorrhagiae & RGA & L. interrogans \\
\hline Icterohaemorrhagiae & Copenhageni & M20 & L. interrogans \\
\hline Icterohaemorrhagiae & Copenhageni & Wijinberg & L. interrogans \\
\hline Icterohaemorrhagiae & Gem & Simon & L. interrogans \\
\hline Icterohaemorrhagiae & Naam & Naam & L. interrogans \\
\hline Icterohaemorrhagiae & Birkini & Birkin & L. interrogans \\
\hline Icterohaemorrhagiae & Mwogolo & Korea & L. interrogans \\
\hline Javanica & Javanica & Veldrat Batavia 46 & L. borgpetersenii \\
\hline Javanica & Menoni & Kerala & L. borgpetersenii \\
\hline Panama & Panama & $\mathrm{CZ} 214 \mathrm{~K}$ & L. noguchii \\
\hline Pomona & Pomona & Pomona & L. interrogans \\
\hline Pomona & Proechimys & $1161 \mathrm{U}$ & L. noguchii \\
\hline Pomona & Tropica & CZ 299 & L. santarosai \\
\hline Pyrogenes & Pyrogenes & Salinem & L. interrogans \\
\hline Pyrogenes & Hamptoni & Hampton & L. borgpetersenii \\
\hline Sejroe & Wolffi & $3705^{1}$ & L. interrogans \\
\hline Sejroe & Trinidad & TRVL 34056 & L. santarosai \\
\hline Semaranga & Patoc & Patoc I & L. biflexa \\
\hline Shermani & Shermani & $1342 \mathrm{~K}$ & L. santarosai \\
\hline Shermani & Carimagua & 9160 & L. noguchii \\
\hline
\end{tabular}


PCR based assay - PCR was performed by using a single primer iRep1 (5'GCG GAC TCA TAC CCG CT 3') used by Barochii et al. (2001) to differentiate Leptospira sp. The PCR mix included 100 ng of DNA from each strain, 100 pmol of primer, $2.5 \mathrm{mM} \mathrm{MgCl}_{2}, 1 \mathrm{X}$ PCR buffer, $200 \mu \mathrm{M}$ deoxynucleotide triphosphates and $1 \mathrm{U}$ (Unit) of Taq polymerase in a final volume of $25 \mu \mathrm{l}$. To prevent evaporation, $25 \mu 1$ of mineral oil was added to each tube. Amplification reactions were carried out in a Eppendorf thermal cycler using the following profile: an initial denaturation at $94^{\circ} \mathrm{C}$ for 5 min followed by 35 cycles of amplification. Each cycle consisted of denaturation at $94^{\circ} \mathrm{C}$ for $30 \mathrm{~s}$, annealing at $50^{\circ} \mathrm{C}$ for $90 \mathrm{~s}$, and extension at $72^{\circ} \mathrm{C}$ for $4 \mathrm{~min}$, with a final extension time of $7 \mathrm{~min}$. All reagents used were from Gibco BRL, Grand Island, NY. PCR was performed on all test samples five times to evaluate the reproducibility of the test. For each assay, PCR products were electrophoresed in $1.5 \%$ agarose gels containing ethidium bromide $0.5 \mu \mathrm{g} / \mathrm{ml}$ and viewed under UV illumination and documented using gel Doc EQ (BioRad) with Quantity One software according to the manufacturer's instructions.

Microscopic agglutination test with group-specific rabbit antisera - The 40 isolates were screened against group-specific rabbit antisera representing serogroups following standard procedures to determine the serogroup. An isolate was considered to belong to the serogroup of the group serum that gave the highest titer (Dikken \& Kmety 1978).

\section{RESULTS}

The results were reproducible all five times each strain was tested. Fig. 1 shows PCR fingerprints of the reference strains. PCR was able to discriminate the serogroups Andamana, Ballum, Canicola, Grippotyphosa, Hebdomadis, Icterohaemorrhagiae, Javanica, Sejroe, Semaranga, and Shermani. The iRep1-PCR assay results from serogroup Icterohaemorrhagiae showed all serovars evaluated shared a similar pattern.
There were no bands by PCR present corresponding to serogroups Australis, Autumnalis, Bataviae, Celledoni, Cynopteri, Djasiman, Panama, Pomona, Pyrogenes, and Tarassovi (data not shown).

The 14 isolates characterized previously by CAAT (Sakata et al. 1992) as serovar Copenhageni all shared common PCR pattern features as well as pattern features characteristic of the serogroup Icterohaemorrhagiae. Similarly, PCR results from two isolate characterized as serovar Canicola and one isolate characterized as serovar Castellonis were in agreement with CAAT results when compared with the reference strains (Fig. 2). One strain belonging to serogroup Pomona did not show any bands by PCR (data not shown).

Fig. 3 shows the representative PCR fingerprints of clinical isolates. In comparison to the reference bank strains used in this study, PCR results of the 40 clinical isolates showed that 39 (97.5\%) belong to serogroup Icterohaemorrhagiae since all fingerprints were identical and one $(2.5 \%)$ belonged to serogroup Sejroe. The single strain isolated from urine belonged to serogroup Icterohaemorrhagiae. These results are in agreement with microscopic agglutination test with group-specific rabbit antisera.

\section{DISCUSSION}

Leptospirosis are frequent in Brazil despite the warm tropical weather accompanied by heavy rainfall (Romero et al. 2003). Because of the association of certain leptospiral serogroups and serovars with severe disease manifestation and complications, an assay that can rapidly and easily identify and distinguish among serogroups or serovars during an outbreak is needed. No further information was available regarding the status of leptospire isolates in São Paulo after 1989 (Sakata et al. 1992) and the number of isolates was very low. The common infecting leptospires reported from São Paulo include serovars Copenhageni (77.78\%), Canicola (11.11\%), Castellonis (5.55\%), and the serogroup Pomona (5.55\%) (Sakata et al. 1992). Since then,

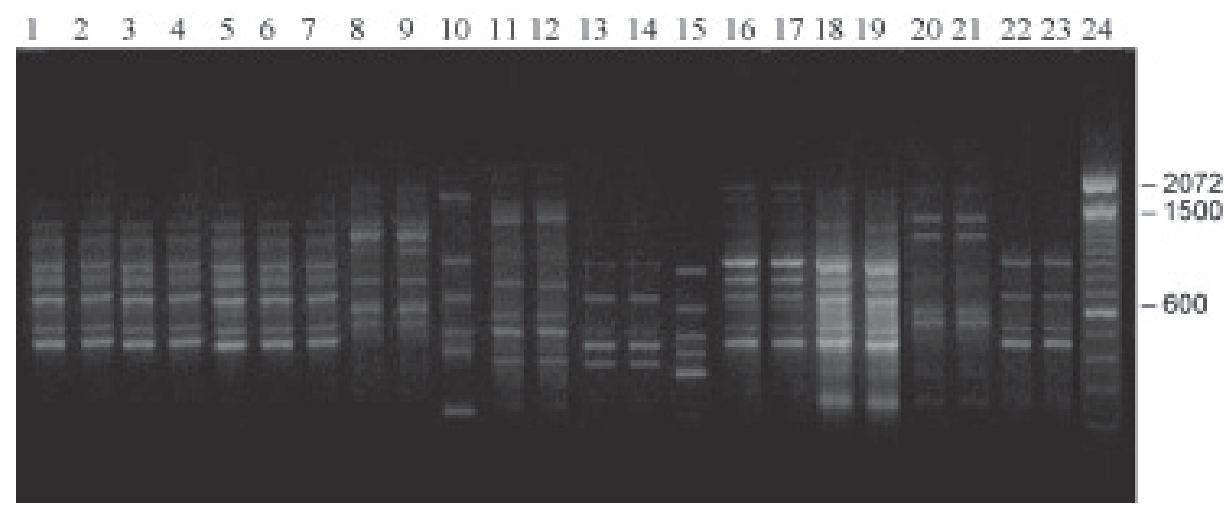

Fig. 1: iRep-PCR fingerprints of reference strains from the genus Leptospira sp. listed in the Table. Lanes - 1: serovar Icterohaemorrhagiae strain RGA; 2: serovar Mwogolo strain Korea; 3: serovar Copenhageni strain Wijinberg; 4: serovar Gem strain Simon; 5: serovar Copenhageni strain M20; 6: serovar Naam strain Naam; 7: serovar Birkini strain Birkin; 8: serovar Javanica strain Veldrat Batavia 46; 9 serovar Menoni strain Kerala; 10: serovar Andaman strain CH11; 11: serovar Shermani strain 1342K; 12: serovar Carimagua strain 9160; 13: serovar Wolfii strain 3705; 14: serovar Trinidad strain TRVL 34056; 15: serovar Patoc strain Patoc I; 16: serovar Hebdomadis strain Hebdomadis; 17: serovar Kremastos strain Kremastos; 18: serovar Grippotyphosa strain Moskva V; 19: serovar Valbuzzi strain Valbuzzi; 20: serovar Castellonis strain Castellon 3; 21: serovar Ballum strain Mus 127; 22: serovar Canicola strain Hond Utrecht IV; 23: serovar Bafani strain Bafani; 24: molecular size marker, DNA ladder (100-bp-Invitrogen) for the range 100-2072 bp. 


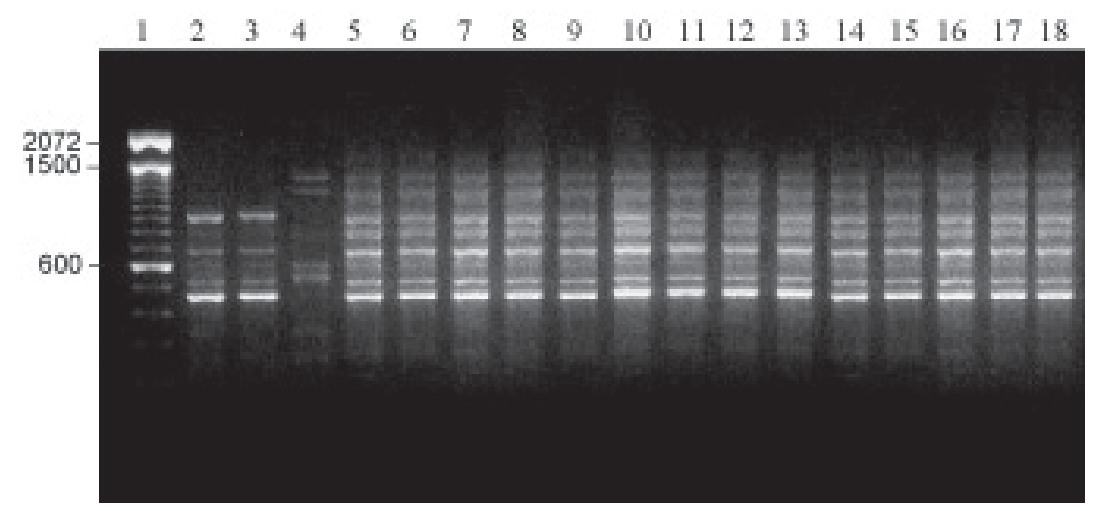

Fig. 2: iRep1-PCR fingerprints of Leptospira strains characterized by cross aglutinin absorption test. Lanes - 1: molecular size marker, DNA ladder (100-bp-Invitrogen) for the range 100-2072 bp; 2-3: serogroup Canicola serovar Canicola; 4: serogroup Ballum serovar Castellonis; 5-18: serogroup Icterohaemorrhagiae serovar Copenhageni.

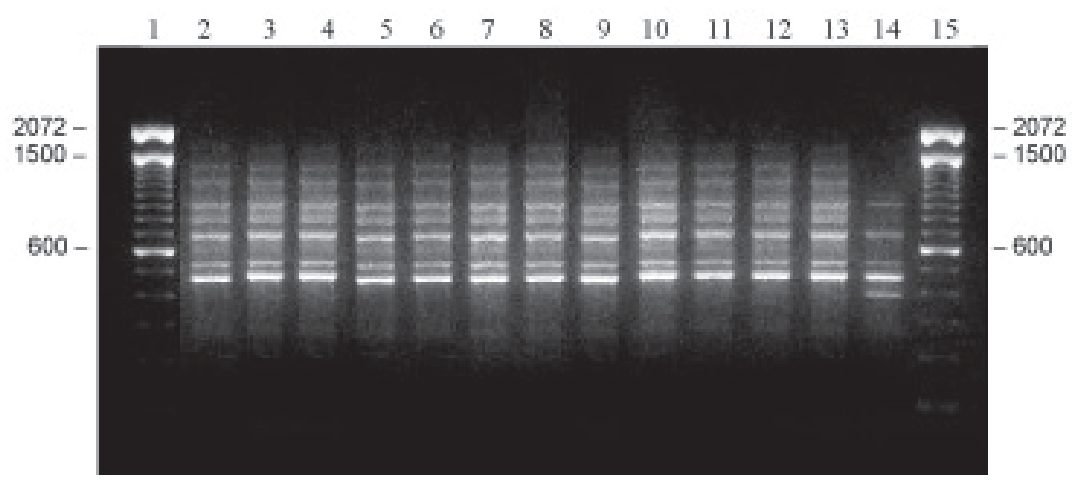

Fig. 3: representative iRep1-PCR fingerprints of some Leptospira strains isolated from patients with leptospirosis obtained between 19951999. Lanes - 2-13: serogroup Icterohaemorrhagiae; 14: serogroup Sejroe; 1 and 15 represent 100bp size markers (100-bp-Invitrogen) for the range 100-2072 bp.

several isolates of leptospires have been obtained and attempts have been made to characterize these strains. Toward this goal, we have isolated and examined Leptospira strains from patients diagnosed with leptospirosis in several parts of the city of São Paulo, Brazil.

Traditional serological typing of leptospiral isolates is a difficult and labor-intensive process involving the use of cross-absorption agglutination reactions and a large collection of rabbit antisera. A rapid and accurate method for typing leptospires from clinical samples is essential for medical diagnosis and treatment as well as isolation and control of the spread of leptospirosis. PCR has been used as an alternative approach to current methods. The choice of a molecular typing method will depend upon the needs, skill level, and resources of the laboratory. Compared with the current commonly used methods in genetic classification, PCR has the advantages of rapidity, simplicity and low-cost. PCR is the least expensive molecular typing method available (Olive \& Bean. 1999). In previous study of Barochii et al. (2001), the value of i-Rep1 PCR fingerprinting for identifying Leptospira isolates was demonstrated.

Our study indicates that iRep1 PCR fingerprinting is one of the simplest methods for characterizing the iso- lates on the serogroup level. This method produced bands that were distinct and reproducible. The PCR results with i-Rep1 were consistent with the results of MAT using rabbit antisera. The fingerprints of both the older (Fig. 2) and more recently collected isolates belonged to the serovar Copenhageni (Fig. 3). However, the PCR assay was not able to distinguish among isolates at the serovar level. In the present study, it was found that strains belonging to the same serogroup showed similarities even if they belong to different genomospecies such as serogroup Shermani serovars Shermani and Carimagua, serogroup Canicola serovars Canicola and Bafani, serogroup Grippotyphosa serovars Grippotyphosa and Valbuzzi and serogroup Sejroe serovars Wolffi and Trinidad.

One disadvantage of the PCR assay was the inability to distinguish among some serovars. However, since serogroup Icterohaemorrhagiae is the prevalent serogroup found in São Paulo, Brazil (Sakata et al. 1992, Romero et al. 2003), the local utility of the PCR assay was demonstrated. Also, the PCR assay using the iRep1 primer could differentiate serovar Canicola and serovar Castellonis, two other serovars isolated from the patients in São Paulo (Sakata et al. 1992). Furthermore, one isolate belonging to serogroup Sejroe was demonstrated in the present study. 
The ability to discriminate these serovars should provide a useful tool in epidemiology. The PCR method was found to be a powerful method for the identification of leptospires at the serogroup level.

One characteristic that is important for introduction of a molecular typing method into a clinical laboratory is the ability of the method to allow analysis of large number of samples. In laboratories involved in large epidemiological studies, high-throughput capability is essential. Simple techniques with discriminatory power and low cost such as iRep1-PCR may be most suitable. Molecular typing techniques such as PCR, are increasingly being used for typing of leptospiral strains because they are both simple and rapid and are therefore often preferred over methods like cross-absorption agglutination test and nucleic acid hybridization. This rapid identification of the etiologic agent in outbreaks and the differentiation of leptospiral serogroups are critical in preventing high mortality associated with certain serogroups.

The disadvantage of genetic typing is the inability to distinguish at the serovar level using arbritrarily or randomly primed polymerase chain reaction (Letocart et al 1997, Pereira et al. 2000, Roy et al. 2003, Natarajaseenivasan et al. 2004, 2005), allele-specific amplification (Woo et al. 1997), low-stringency single specific primer PCR (Oliveira et al. 2003), PCR using insertion element sequences (Zuerner \& Bolin, 1997, Machang'u et al. 2004) and PCRrestriction fragment length polymorphisms (Woo et al. 1997). Nevertheless, these techniques may still be helpful in discriminating serogroups during outbreaks.

In conclusion, our study shows that this technique will improve the identification of leptospires at the serogroup level for epidemiological survey. The use of the PCR assay eliminates the need for difficult and timeconsuming techniques such as maintenance of reference serum batteries, dark-field microscopy and preparation of homologous rabbit antiserum used for serologic assays. However, this method should be complemented by conventional methods such as CAAT for the identification of Leptospira isolates at serovar level.

\section{ACKNOWLEDGMENTS}

To Roberta Morozetti Blanco, Jonas Umeoka Yamauchi, and Mônica Viana de Lima for technical assistance in PCR assays; Dr Albert I Ko, Mônica Georgete Scola, and Lia Teixeira Bastos for providing some strains of Leptospira sp., and Dr Randy Johnson for English language revision of this manuscript.

We have received appropriate ethics approval from Instituto Adolfo Lutz to realize this work.

\section{REFERENCES}

Barochii MA, Ko AI, Ferrer SR, Faria MT, Reis MG, Riley LW 2001. Identification of new repetitive element in Leptospira interrogans serovar Copenhageni and its application to PCR-based differentiation of Leptospira serogroups. J Clin Microbiol 39: 191-195.

Bharti AR, Nally JE, Ricaldi JN, Matthias MA, Diaz MM, Lovett MA, Levett PN, Gilman RH, Willing MR, Gotuzzo E, Vinetz JM, and Peru-United States Leptospirosis Consortium 2003. Leptospirosis: a zoonotic disease of global importance. Lancet Infect Dis 3: 757-771.
Correa MO, Hyakutake S, Natale V, Tiriba CA, Martirani I, Galvão PA, Albano A, De Filippi J, Fahrat CK, Neto VA 1971. Leptospirose humana por Leptospira andamana. Rev Inst Med Trop São Paulo 13: 137-143.

Dikken H, Kmety E 1978. Serological typing methods of leptospires. Methods Microbiol 11: 259-307.

Faine S, Adler B, Bolin C, Perolat P 1999. Leptospira and Leptospirosis, 2nd ed., MediSci, Melbourne, Australia.

Hermann JL, Bellenger E, Perolat P, Baranton G, Saint-Girons I 1991. Pulsed-field gel electrophoresis of NotI digests of leptospiral DNA: a new rapid method of serovar identification. J Clin Microbiol 30: 1696-1702.

Korver H, Kolk AHJ, Vingerhoed J, Leeuwen JV, Terpstra WJ 1988. Classification of serovars of the Icterohaemorrhagiae serogroup by monoclonal antibodies. Isr J Vet Med 44: 1518.

Letocart M, Baranton G., Perolat P 1997. Rapid identification of pathogenic Leptospira species (Leptospira interrogans, L. borgpetersenii, and L. kirschneri) with species-specific DNA probes produced by arbitrarily primed PCR. J Clin Microbiol 35: 248-253.

Levett PN 2001. Leptospirosis. Clin Microbiol Rev 14: 296326.

Machang'u RS, Mgode GF, Assenga J, Mhamphi G, Weetjens B, Cox C, Verhagen R, Sondij S, Goris MG, Hartskeerl RA 2004. Serological and molecular characterization of leptospira serovar Kenya from captive African giant pouched rats (Cricetomys gambianus) from Morogoro Tanzania. FEMS Immunol Med Microbiol 41: 117-121.

Natarajaseenivasan K, Prabhu N, Selvanayaki K, Raja SSS, Ratnam S 2004. Human leptospirosis in Erode, South India: serology, isolation, and characterization of the isolates by randomly amplified polymorphic DNA (RAPD) fingerprinting. Jpn J Infect Dis 57: 193-197.

Natarajaseenivasan K, Vijayachari P, Sharma S, Roy S, Sugunan AP, Biswas D, Sehgal SC 2005. Phylogenetic relatedness among leptospiral strains belonging to same serovar recovered from patients with different clinical syndromes. Infect Genet Evol 5: 185-191.

Olive DM, Bean P 1999. Principles and applications of methods for DNA-based typing of microbial organisms. J Clin Microbiol 37: 1661-1669.

Oliveira MA, Caballero OL, Vago AR, Harskeerl RA, Romanha AJ, Pena SD, Simpson AJ, Koury MC 2003. Low-stringenct single specific primer PCR for identification of Leptospira. J Med Microbiol 52: 127-135.

Pereira MM, Matsuo MG, Bauab AR, Vasconcelos SA, Moraes ZM, Baranton G, Saint Girons I 2000. A clonal subpopulation of Leptospira interrogans sensu stricto is the major cause of leptospirosis outbreaks in Brazil. J Clin Microbiol 38: 450-452.

Perolat P, Mérien F, Ellis WA, Baranton G 1994. Characterization of Leptospira isolates from serovar hardjo using ribotyping, arbitrarily primed PCR and mapped site polymorphisms. J Clin Microbiol 32: 1949-1957.

Ramadass P, Jarvis BDW, Corner RJ, Penny D, Marshall RB 1992. Genetic characterization of pathogenic Leptospira species by DNA hybridization. Int J Syst Bacteriol 42: 215219. 
Romero EC, Bernardo CCM, Yasuda PH 2003. Human leptospirosis: a twenty-nine-year serological study in São Paulo, Brazil. Rev Inst Med Trop São Paulo 45: 245-248.

Roy S, Biswas D, Vijayachari P, Sugunan AP, Sehgal, SC 2003. Antigenic and genetic relatedness of Leptospira strains isolated from the Andaman Islands in 1929 and 2001. J Med Microbio 52: 909-911.

Sakata EE, Yasuda PH, Romero EC, Silva MV, Lomar AV 1992. Sorovares de Leptospira interrogans isolados de casos de leptospirose humana em São Paulo, Brazil. Rev Inst Med Trop São Paulo 34: 217-221.
Woo THS, Patel BKC, Smythe, LD, Symonds ML, Norris MA, Dohnt MF 1997. Comparison of two PCR methods for rapid identification of Leptospira genospecies interrogans FEMS Microbiol Lett 155: 169-177.

Yasuda PH, Steigerwalt AG, Sulzer KR, Kaufmann AF, Rogers F, Brenner DJ 1987. Deoxyribonucleic acid relatedness between serogroups and serovars in the family Leptospiraceae with proposals for seven new Leptospira species. Int J Syst Bacteriol 37: 407-415.

Zuerner RL, Bolin C 1997. Differentiation of Leptospira interrogans isolates by IS1500 hybridization and PCR assays. J Clin Microbiol 35: 2612-2617. 